\title{
Indigenous Wisdom for Developing Economic Life: Case of Yokari People, West Papua
}

\author{
Jhon Urasti Blesia ${ }^{\circledR}$, Westim Ratang ${ }^{1}$ \\ ${ }^{1}$ Universitas Cenderawasih, Indonesia
}

DOI: http://dx.doi.org/10.15294/komunitas.v8i2.7034

Received : 25 August 2016; Accepted: 19 September 2016; Published: 30 September 2016

\begin{abstract}
Natural resources need to be used to improve the economic life based on the indigenous local wisdom. This is one of Jayapura regency's economic development programs to increase the welfare of the whole society as mandated by the special autonomy policy in West Papua. This study aims to address the potential of natural resources in Yokari customary council by utilising their local knowledge to improve the economic life of the community. The use of qualitative research and triangulation method for data collection and analysis are used and purposive sampling method employed to answer the expected objectives of this study. The head of village government, Ondowapona, elders and religious leaders were approached for in-depth interviews in addition to the observation and secondary data study that had been largely completed beforehand. The results show that the majority of community work as fishermen and farmers along with the potential of natural resources, being various kind of fish, fruit, and vegetable used for sale or daily consumption in the family. Local wisdom, such as the obligation to protect the environment and customary laws, restriction to fish with the bombs and taboo to work on Sunday are acknowledged and accounts for traditional sanctions that need to be highly considered by the community to engage with the natural resources. Significant challenges faced by the community, such as difficult access to transportation, marketing and distribution channels of their resources need to be seriously taken into account by the government to improve a better quality of the community life.
\end{abstract}

Keywords: economic life; local wisdom; indigenous community, Yokari tribe

\section{INTRODUCTION}

West Papua, one of Indonesia's provinces, located in western part of New Guinea Island has been officially incorporated into Indonesia since 1967. Despite its abundant natural resources and the rainforests characterized by rich biodiversity and geodiversity in the ecosystem, the province has faced significant challenges to develop important sectors of the economy, education, health, and infrastructure (Afiff and Lowe 2007; Alexander 2011; Lane and Corbett 2005; Schlosberg and Carruthers 2010). In order to address these challenges the Government of Indonesia, in consideration of a range of solutions has adopted the Special Autonomy policy for West Papua. This is intended to reduce the gap between Papua province and other regions by improving the welfare of Papuans as well as providing the same opportunities for indigenous Papuans to lead and develop their region.

As specified by the Government Regulation in Lieu of Law No.1 in 2008 (previously Law No.21 in 2001), article No. 43 chapter XI decreed at the Special Autonomy Law addresses the protection of the "adat" rights or local customary rights. West Papua consists of more than 300 different tribes each with strong and rich culture which is deeply attached to their hearts and significantly affects their whole life. The special autonomy policies and implementation are expected to be congruent with the local wisdom of in-
Corresponding author:

Address: ${ }^{2}$ Department of Economic Science, Universitas

Cenderawasih, West Papua, Email : jhon.blesia@

pg.canterbury.ac.nz

Phone : 0226933176 (c) 2016 Semarang State University. All rights reserved p-ISSN 2086 - 5465 | e-ISSN 2460-7320 
digenous communities in Papua.

Jayapura, one of the regencies in $\mathrm{Pa}-$ pua in carrying their responsibility to protect local customary rights owned by Indigenous Papuan communities has formed nine customary councils representing nine major different tribes in the regency as a whole (CSO-Papua et al. 2014). The nine customary councils are Yokari, Sentani, Moi, Tepra, Ormu, Jouwarry, Dumutru, Elseng and Oktim. The regency and all councils signed a memorandum of agreement, following the decree of Regent No. 319 in 2014 on the Recognition and Protection of Indigenous People and the decree No.320 in 2014 on the Formation of Indigenous Villages at the Regency of Jayapura. The agreement is essentially designed to develop a clear paradigm that acknowledges the recognition and protection of indigenous people.

The regency has a high expectation that through the signed memorandum, all nine customary councils can peacefully live and enjoy their recognized and protected indigenous rights. The regency is currently focussing on developing the economic life of all members of society through maximization of potential natural resources, by utilizing indigenous community's local wisdom (Sawaki et al. 2015; Anderson 2006; Castleden and Garvin 2008; Hunt 2008; Jessop and Oosterlynck 2008). The regency believes that by exploring the local wisdom of Jayapura's indigenous community's approach to dealing with their natural resources, the community can improve their family economy and at the same time gain recognition over indigenous rights.

This study aims to address Yokari's economic development in the era of special autonomy in Papua by exploring fully the potential of their own natural resources based on their local wisdom. The Yokari tribe has potential resources and strong indigenous values which they believe in as their local wisdom. These beliefs enable them to manage all resources in order to support community life. Besides this, the location is situated precisely in the administrative area of the government regency. Public infrastructure, such as government buildings, hospital, traditional market and other public facilities are largely built there and therefore the economic life of indigenous and non-indigenous people has significantly changed over time. Richer natural resources, unique local wisdom and the strategic location of Yokari have been the main reasons for choosing Yokari for this study, rather than other local customary councils. The existing studies on local wisdom (Lane and Corbett 2005; Alexander 2011; Schlosberg and Carruthers 2010) rarely gives ethnographic illustrations from a traditional community living in the middle of modern society.

\section{The Glimpse of Yokari Tribe, Tribal Ter- ritory, Leadership, Customary Law, and Cultural Objects}

The word "Yokari" consists of Yo and Kari. Yo means a village or place and Kari, fun or joy. There are three designations for Yokari customary community and the designations have similar meaning for the community. They are Yokari or a place of joy, Yakari or a day of joy and Yekari or hidden joy. Yokari believes that their ancestors were already in the place they currently live, they were not introduced from somewhere else or came from far away to settle there. The indigenous community is those who inhabit the northern coast of Gulf of Tanah Merah, located at the administrative area of Jayapura regency. In general, Indigenous Yokari live and are spread among five main villages; Maruway, Meukisi, Endokisi, Senamay and Buseryo where all villages have formed a district of Yokari and speak the same language. The community has the authority over the region, culture, economy, social life and law that consist of customary rules that are still adhered to and maintained.

The concept of collectivism is used by Yokari community where people have lived together in small groups side by side with other tribes from time immemorial. The relationship of social, economic and cultural interactions with other tribes have been practiced since the time of their ancestors. The tribal area is bounded by stretches of nature, such as rivers, mountains, sea and 
forests, where the boundaries have been collectively agreed upon by all Jayapura tribes. The geographical situation of Yokari are the northern side of the Pacific Ocean, the south is bordered by indigenous territories of Nambluong and Klesi, and the east bordered by indigenous territories of Tepra and Moi tribes and next to the western part is the border with the indigenous Jouwary territory.

The leadership system of the community adopts Ondowapona leadership where a king appointed as the head of customary administration, is supported by chosen people who consist of Tekai (the vice), Werai Baisuna, Wera Eyusuna, Dra Semana, the head of Keret (Touna Yarise) and some heads of family considered as elders in their clans or groups. Ondowapona for Yokari community is positioned at the highest level of indigenous leaders. Ondowapona is a life-time position handed down from generation to generation. A person cannot directly be called Ondowapona and carry its title if he has not been crowned by the community through a traditional ceremony with certain criteria agreed upon. In Yokari tribe, a candidate considered as Ondowapona must have done good deeds and demonstrate an attitude of leadership, the assessment for which takes a very long time. The elders in the tribe, therefore play an important part in intentionally giving clear instructions to guide the crown prince to behave and conduct himself in such a way in order to gain the sympathy of the community.

The customary law of Yokari dictates how the life of the community is regulated through local knowledge derived from the indigenous values without written rules. In their customary laws, decisions and sanctions must be taken by Andowapona where Yarona (someone who is appointed to lead the meeting) will lead the assembly. The meeting to discuss issues needs to be carried out using Yokari language, called Touna-Yau. Sanctions or penalties will apply for all violation such as murder, theft, rape and adultery and the form and level of sanctions will depend on the types of actions committed.

The cultural symbols of the community are specifically related to their hereditary traditions. The paradise bird and tifa "a kind of drum made of wood" are two of many tribal symbols in Yokari community that represent the greatness of Ondowapona as a supreme leader. As a symbol of purity, the paradise bird can only be worn on the crowned head of Ondowapona. It is

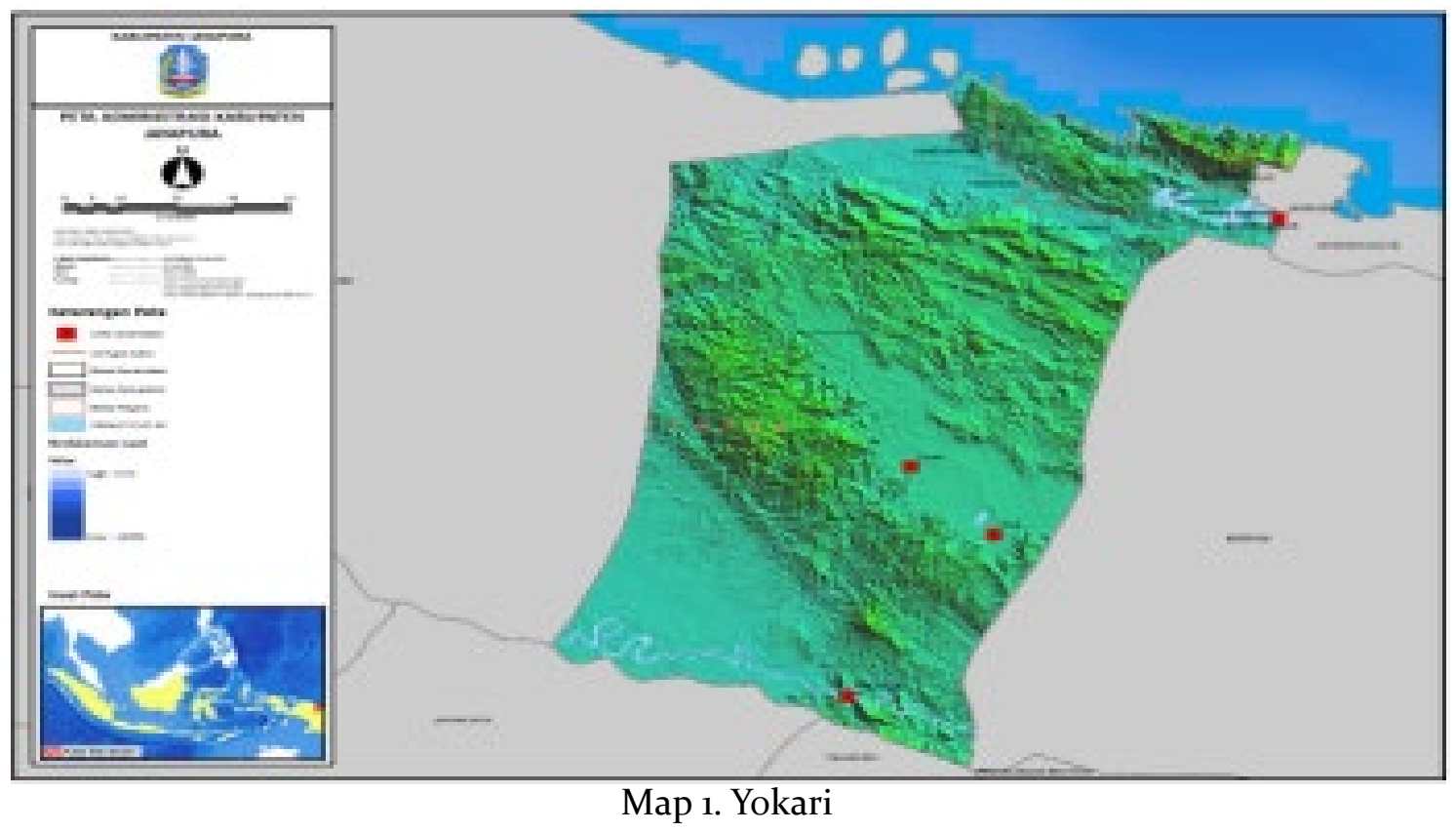

Source: Maruway, Fred, 2014. https://meukisi.wordpress.com/2014/o5/18/peta-kabupaten-yokari/ 


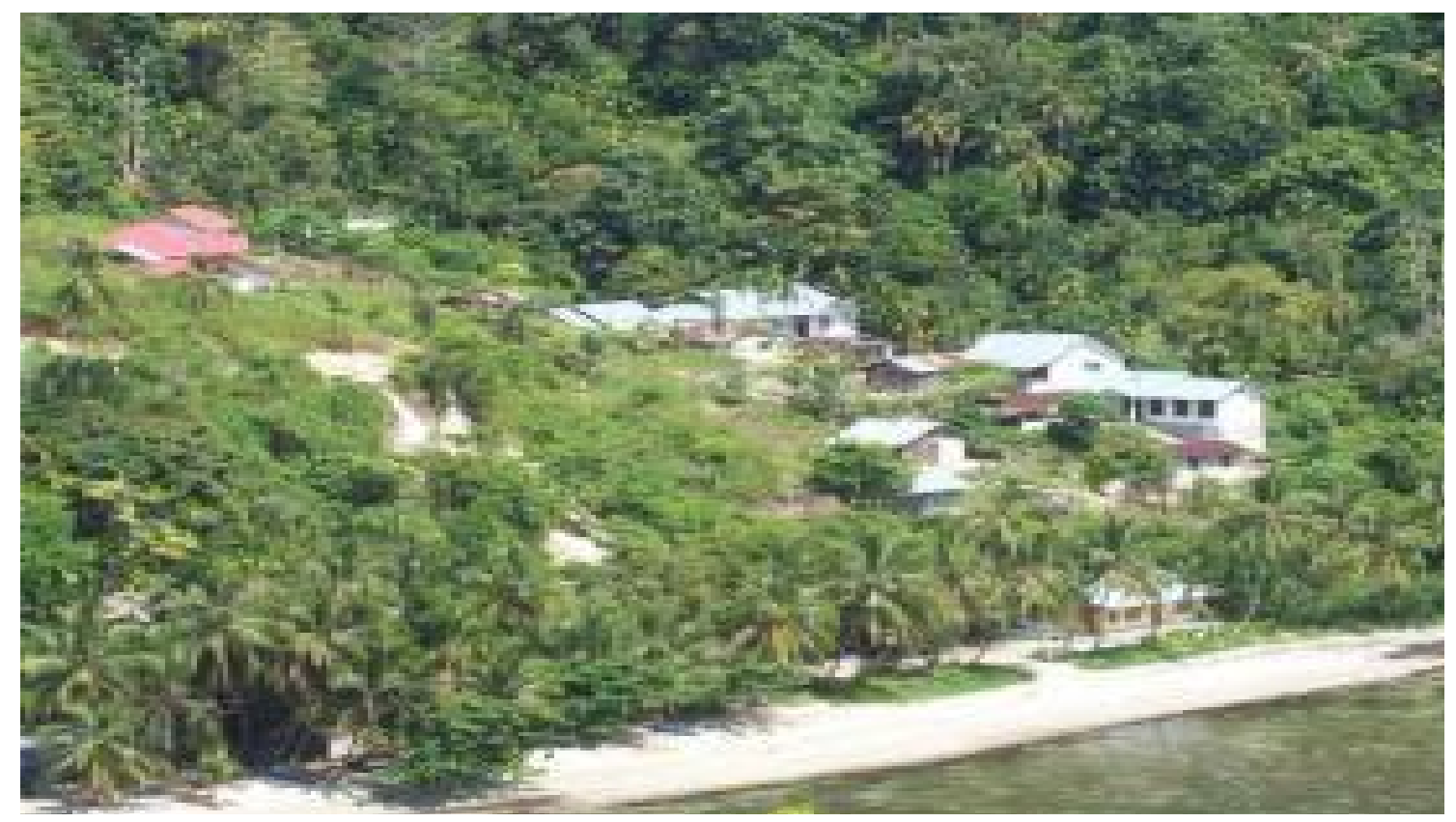

Figure 1. Location of Yokari District

first worn at the time of his coronation as the highest king of Yokari tribe. The paradise bird crown of Ondowapona cannot be used or duplicated by anyone else and its use under any circumstances cannot be justified, as these actions will be subject to heavy punishment. Tifa is an important symbol of the tribe related to the traditional feast. The sound of tifa means a sign of a traditional party, therefore tifa should be sounded in pleasant ways. Tifa will normally be accompanied by songs and traditional dances with the permission of Ondowapona. The cultural symbols, and the art and culture of indigenous Yokari community are very rich in the forms of dance and carving.

\section{RESEARCH METHOD}

Qualitative research is used to explore Yokari indigenous community local wisdom and the way it can be incorporated in developing their economic life. The study utilizes triangulation method for data organization and analysis and purposive sampling method is employed to get information from key persons. The key persons considered to contribute to this research are those who work for Yokari's village government, Ondowapona, elders, religious leaders and other people who are highly respected due to their education, occupation and other important social status in the community. Yokari village government is a formal institution, built around the coastal areas of Yokari working together to support the administration of the village. Those who work for the village government are deemed to understand the various issues of utilization and management of coastal and marine resources as well as the values of local wisdom that thrive in Yokari coastal community. They are the head, vice-head and secretary of the village. Ondowapona, elders and religious leaders are those who live around the community, and are considered to understand the problems of indigenous rituals associated with the natural resources.

Triangulation method is used to collect the data where the combination of data collection techniques such as observation, in-depth interview and secondary data analysis is hired (Torrance 2012). Observation technique is carried out at Yokari council to capture potential natural resources where the object of the observation is focussed on the condition of the village, of the natural resources and local wisdom. Semi-structured interviews are conducted to obtain dee- 
per information, and understand the real oral story and its meaning from the key informants, regarding natural resources, local wisdom and how the local wisdom is used by the community to engage with their natural resources (Rabionet 2011; Tipa and Welch 2006; Veland et al. 2013). Secondary data analysis is used to strengthen the results of observations and in-depth interviews and it includes written report of Yokari's community history, culture, economic life and customary law.

All data collected from observation, in-depth interviews and data secondary are then analysed into three systematic steps, such as data reduction, data presentation and drawing the conclusion. Data reduction includes selection, simplification, abstraction and transformation of rough data that has emerged from in-depth interviews, observations and written materials. Data presentation is a structured information that provides possibilities to draw the conclusion and take actions. Data presentation includes various forms of narrative text, images, tables, and charts. Drawing a conclusion at the final step is done to verify the conclusion through rethinking information during the writing process, reviewing the records in the field and communicating them with other peers in order to ensure the sharpness of the conclusion drawn.

The researchers encountered significant challenges to identify in detail the potential of natural resources in Yokari tribe. The tribal people live in 5 different villages and the characteristics of natural resources are slightly different in each village. We believed that the different potential of the resources from each village should be dealt with differently, and also include strategies identified to manage the natural resources which would contribute to an improvement in the economic life. To solve this problem, the researchers decided that the village that was the most strongly representative of the tribe was the village of Senamai. The main reason was that Yokari natural resources were evident to a greater degree in this village. In spite of the slight difference in each village's natural resources, Senamai village is considered to better portray all the natural resources of Yokari tribe. Ondowapona and most Yokari elders also live in this village, and because of their life experiences they can identify more Yokari's local wisdom relating to natural resources.

\section{Economic Condition and Potential Natural Resources}

\section{Economic Condition}

The researchers were brought to the village of Senamai where Ondowapona and most Yokari elders currently live. Senamai is the village formed before the expansion area of Yokari district; the northern part is bordered with Vim village, south is Nenomani village and east is the district of Yokari. The village is more isolated further compared to other villages in the district. The topography of Senamai village is mostly covered by the sea, located at sea level at 19.5 meters with the total rainfall of $45 \mathrm{~mm} /$ year and the average temperature of $35 \mathrm{c}$. Due to the close proximity to the sea, the majority of the community work as fishermen, where traditional fishing is practiced. Fishing is performed in a group from morning to evening without any fishing technology. The fish they catch will normally be sold to other people at the traditional market and the unsold fish will be consumed for their daily life.

The population of this village consists of $\mathbf{2 5 0}$ heads of household. This number is fairly small compared to the size of the area. There are two neighbourhoods of Yokari living close together and working in groups to collect natural resources from the sea and forest. The development of this village is rapidly increasing on account of one of Indonesia's central government programs through the special autonomy policy which provides particular funding to develop the village. Besides the rich sea resources which provide a large amount of sand and stone, the heavy forest cover around the village has also brought a huge potential for materials for building and construction. One of the barriers in undertaking economic activities is the transportation because sea and land transportation, as the two main forms of transport to the city is very expensive. The 


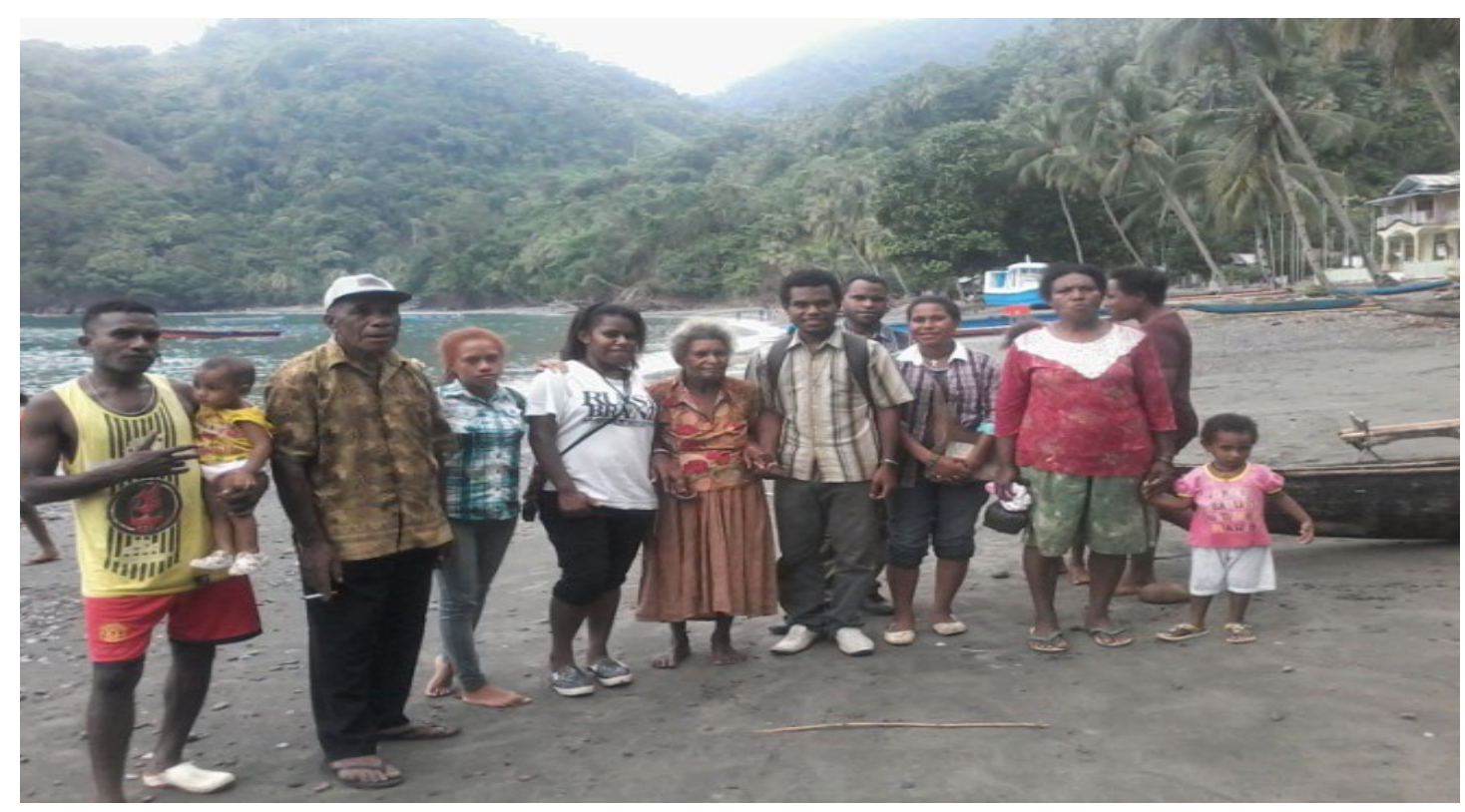

Figure 2. Yokari's community, taken during data collection process

community can spend 700,00o rupiahs (around $70 \mathrm{NZ}$ dollar) for land transportation and 500,00o rupiahs (around 50 NZ dollars) for sea transportation to market their fish and other natural resources in the main city. This is considered high according to the level of economy and currency in Indonesia, especially in remote West Papua. For this type of community, where most of the inhabitants work as fishermen, transportation costs will be the greatest expenditure. This then can impede other economic activities, such as distribution of food and clothing to the village.

Much of the Yokari area is used to build Jayapura government's office buildings, public facilities, and infrastructure. To participate in the current development of the regency, many non-indigenous people from other regencies and cities of Indonesia spread and build their business around the district. As a result of Indonesia's transmigration program, many people from other provinces in Indonesia arrive to make a living in this regency. This situation creates a significant gap between the non-indigenous population and indigenous Yokari's people where most indigenous people choose to live close to the sea, so they can still practice their traditional activities and use local wisdom to manage their natural resources. This is why the researchers also understand that the nature and obligations to protect it are very important for Yokari's tribe.

\section{Potential Natural Resources}

The researcher conducted in-depth interview with Ondowapona, the head of the government village and some elders at the village of Senamai. The results of our interview with the participants gathered a number of interesting findings related to the potential of nature and the sea owned by the village. The study found that the daily fishing of the Yokari coastal communities is performed by the men while farming and gardening by women. The potential of the marine resource in the village includes various kind of fish that can create high income for the community. The caught fish can be directly sold or heated on the fire before being sold. Although most of the natural resources are derived from the sea, fruit trees, such as mango and matoa are also owned by the village and can be harvested in certain seasons in order to be sold at the traditional market or consumed in the family.

Here is the summary of the in-depth interview with participants in this research.

(Translated) “...........daily activities of people in Yokari men are mostly fisher- 
men and .......for women, they usually farm (planting tubers and vegetables). The most natural resource is derived from the sea, fish.... And some fruits such as mango and matoa that people can harvest at certain seasons. Fresh fish for most people is normally sold to the market.........but some people usually heat it first... and then sell it". - Yokari Ondowapona.

(Translated) "...........because the sea is full of wave, it is difficult to fish.....but now I see people have used boat operated by machine". - One of the Elders.

The results also found that in addition to the economic potential of fish, the female community have certain skills to make cakes from cassava and taro from the crops in their gardens. The camshaft made of bark and carving are also produced by the women. All these skills are then used as tools to create extra income for their family and support their husband in order to pay for education, food, and clothing. Farming and gardening also create significant benefits for the local community. In addition to rice, the community also relies on the cassava, taro and sago as staple food consumed in daily life or sold in the market. Indigenous Yokari women understand their role in the family to support the family's economic life.

The findings also indicate that the community has certain kinds of assistance through the government aid program funded by the special autonomy budget in the form of boats, gas lamps and fishing tools. The assistance is meant to facilitate the local people to find and manage their natural resources in order to better support themselves in their daily work and life. The local government approached the people by several visits to evaluate the needs and expectations and made effort to develop economic life. Through Special Autonomy program to increase economy based on indigenous standpoint, the government works to reach the vision. However, apart from the assistance provided, the main obstacles faced by the community which impacts on their ability to go fishing are the ocean conditions, such as large waves. Therefore, through using technology the community is able to catch more fish.

\section{Yokari's Local Wisdom and Sanctions in Dealing with the Natural Resources}

This study defines local wisdom according to Saptomo (2010) in that it comprises all forms of knowledge, belief, insight, understanding, customs, and ethics that function as a guidance for human behavior and conduct in life in ecological communities. All forms of local wisdom are internalized practices, taught and passed down through generations and form patterns of human behavior towards their fellows of human beings, towards nature and towards the supernatural. Sumarmi (2015) suggested that local wisdom includes the aspects of local knowledge, religion, folklores, local beliefs, prohibition and suggestion. Religion plays an important role in the local wisdom (Radix A.P. Jati 2014). Yokari indigenous community has local wisdom that exists to guide them in engaging with other people, nature and with the environment in which they live. It then teaches them how to live and approach life according to what has been accepted which includes how to preserve the natural resource given from God.

In the preservation of natural resources through the local wisdom at the village of Senamai, the tribe follows the community rules inherited from the indigenous cultural values of the ancient ancestors and agreed by Ondowapona, elders and all community. The community believes that natural resources and culture have a very strong correlation where nature will be disrupted when not properly treated. The community also believes that compliance with the customary rules will actually contribute as much as possible to the common good. Apart from the sanctions considered as the consequences if these rules are breached, the rules are basically designed to maintain the universe and that includes the environment in which the Yokari live.

Here are indigenous Yokari's local wisdom and sanctions in dealing with the natural resources. 


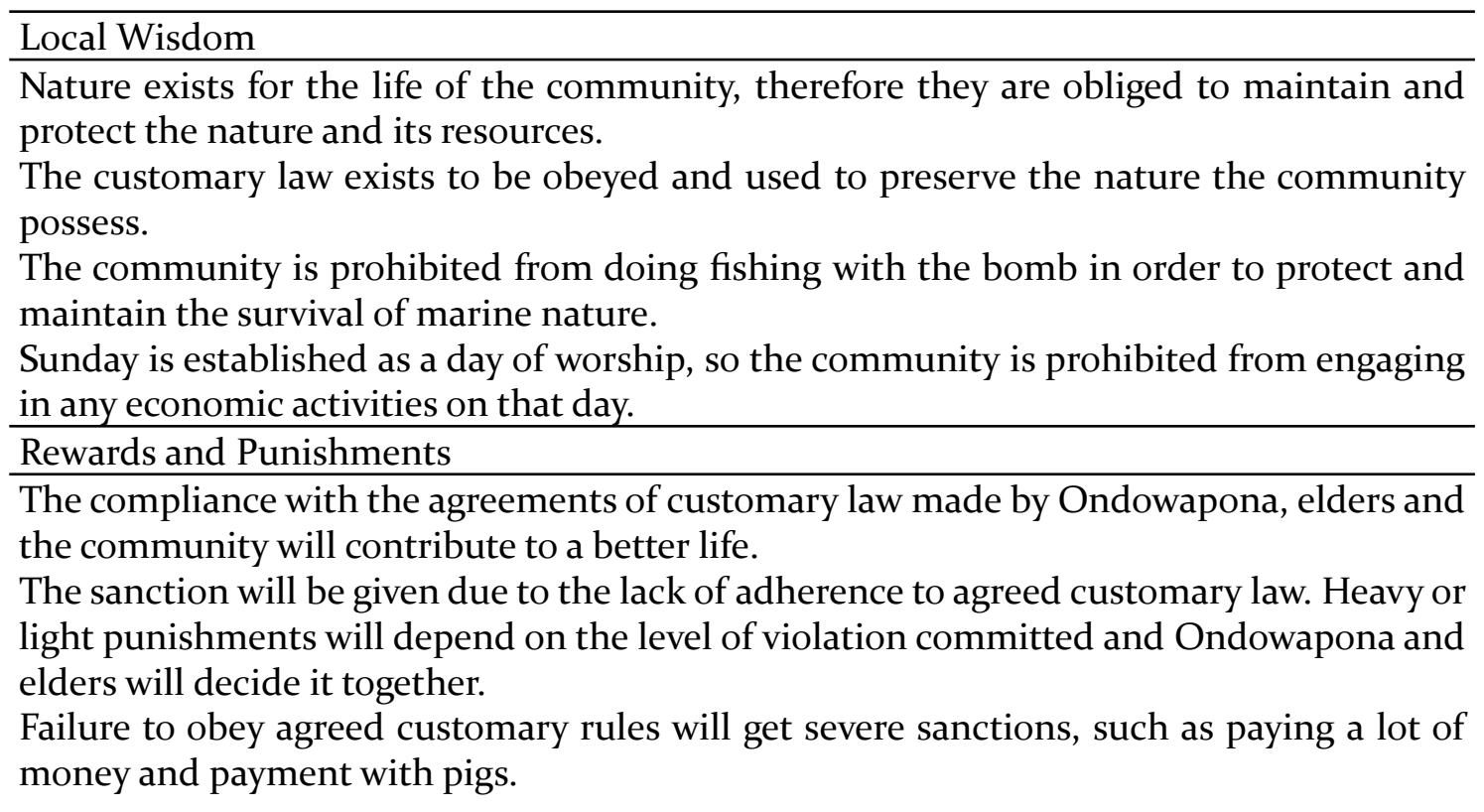

The table above explains both local wisdom and sanctions in dealing with the natural resources owned by Yokari tribe at the village of Senamai. The principles of local wisdom are basically designed to guide and teach the community to highly respect the valuable resources God has provided. Nature exist to be utilized for the benefit of life, therefore it needs to be maintained and protected, not to be destroyed for any reason. Fishermen at the village in their daily work have understood that compliance with the customary rules will help them to get more fish, they will be safe at work and arrive home for their families. Fishermen also understand that disobedience to the local wisdom will cause suffering, they will not catch a lot of fish and therefore there will be less income for their family. These simple beliefs, conceptualized as local wisdom guide the villagers to live and deal with their natural resources every day.

\section{Jayapura Regency's Important Strate- gies to Develop Yokari Economic Life}

A strategy is a careful plan of the activities to achieve specific goals. Mardikanto (2009) explained that strategy is an important process in the implementation and control of the activities undertaken to succeed in the competition. Economic development strategies for the indigenous community are the strategies to accelerate the structural transformation to strengthen the position and role of the community in the economy. Therefore it is important for the Government of Jayapura to choose important strategies to develop Yokari's community economic life.

Based on the triangulation method, the researchers decided upon three strategies to advise the Government to improve the economic life of Yokari tribe. First, the difficult access to land and sea transportation as well as the high costs for the distribution of resources to the market need serious consideration by the government. The same attention needs to be given to the related issue of transport security and safety in an effort to make access to markets more reliable. The special autonomy fund provided by the Government of Indonesia needs to be used to provide more sea and land transportation with a lower tariff. The government also needs to facilitate a higher level of safety and security at sea and with land transportation so the tribal communities will know that they are safe. Hiring highly skill drivers and provision of sophisticated machine for transportation could be the alternatives the government can think about.

Secondly, the government needs to develop production centers, particularly in the areas of fisheries and agriculture as well as open areas of marketing and ensure suf- 
ficient distribution channels for the local community in order to improve the welfare of the community. The potential fish and fruit in the village can be processed by technology into finished products ready for sale, the centers of production to process the raw materials, therefore, need to be provided by the government. To heat fish, for example, villagers can use an environmentally friendly machine instead of using open fire. Further study needs to be done to research the type of machine used. The government also needs to facilitate ways for the community to market and distribute the resources. Seeking distributors of fish and fruit or collaborating with local companies to supply the resources can be alternative channels for marketing and distribution. Thirdly, Yokari potential fisheries are very large, leading to a large number of fishermen, therefore the fishermen need to be given training in how to find or catch fish more safely. The introduction of modern technology can be done by taking into account the indigenous values and the concept of sustainability.

\section{CONCLUSION}

The study emphasizes Yokari's local wisdom to deal with the potential of natural resources to develop their economic life. The community currently lives in the era of special autonomy policy, one of Indonesia central government programs to improve Papuans' welfare and provide the same opportunities with in other regions of Papuans. Papua's strong and rich culture, different and unique between each tribe requires the Government of Jayapura regency to currently focus on developing the community's economic life through their local wisdom. The local wisdom of the community related to the natural resources is essentially congruent with the concept of sustainability.

The facts that the northern part of Yokari is in the Pacific Ocean, and most people live in the coastal areas, Yokari's potential for fisheries and agriculture are huge in the areas where the usual livelihood of Yokari tribe are fishing and gardening. Fishing is mainly performed by men while planting and gardening by women and all activities are collectively done in traditional ways and small groups. Various kind of fish and fruit are used for sale or daily consumption in the family. The income they gain is normally used to pay the cost of education, food, and clothes, therefore husband and wife in the family support each other to earn more money.

To manage the natural resources the community must comply with the local knowledge they have from their ancestors. Understanding that the existence of nature is purely used to support life and therefore needs to be kept and protected. The community is not allowed to do fishing with a bomb and work is prohibited on Sunday as it is the day of worship. By respecting these indigenous values, the community will have a better life and failure to obey, on the other hand, will lead to suffering, and various sanctions will follow.

The Government of Jayapura regency was advised of three important strategies to help Yokari's community to improve their economic life using their natural resources, while at the same time preserving their local wisdom. More provision of sea and land transportation and consideration of security and safety on transportation systems, establishment of production centres in fisheries and agriculture as well as open areas of marketing and distribution channels and training for the fishermen to use modern environmentally friendly technology in their work are the strategies the researchers can give to the government through this study.

\section{ACKNOWLEDGEMENTS}

This research has been funded fully by the Department of Research and Development, the Government of Jayapura Regency. The content of this study does not necessarily reflect the views or policies of the Department of Research and Development.

\section{REFERENCE}

Afiff, S. and Lowe, C., 2007. Claiming indigenous community: Political discourse and natural resource rights in Indonesia. Alternatives, 32(1), pp.73-97.

Alexander, J.C., 2011. Market as narrative and character: For a cultural sociology of economic life. 
Journal of Cultural Economy, 4(4), pp.477-488.

Anderson, R.B., Dana, L.P. and Dana, T.E., 2006. Indigenous land rights, entrepreneurship, and economic development in Canada:"Opting-in" to the global economy. Journal of world business, 41(1), pp.45-55.

Castleden, H. and Garvin, T., 20o8. Modifying Photovoice for community-based participatory Indigenous research. Social science $\mathcal{E}$ medicine, 66(6), pp.1393-1405.

CSO-Papua, $\mathrm{AFP}_{3}$, PPMA \& Universitas Cenderawasih 2014. Membangun Model Pemerintahan Kampung Adat di Kabupaten Jayapura, Jayapura, $\mathrm{AFP}_{3}$ Papua.

Hunt, J., 2008. Between a rock and a hard place: Self-determination, mainstreaming and Indigenous community governance. Contested governance: culture, power and institutions in Indigenous Australia. CAEPR Research Monograph, (29), pp.27-53.

Jessop, B. and Oosterlynck, S., 2008. Cultural political economy: On making the cultural turn without falling into soft economic sociology. Geoforum, 39(3), pp.1155-1169.

Lane, M.B. and Corbett, T., 2005. The tyranny of localism: indigenous participation in communitybased environmental management. Journal of Environmental Policy and Planning, 7(2), pp.141-159.

Mardikanto, 2009. Sistem Penyuluan Pertanian. Sebelas Maret University Presss, Surakarta.

Rabionet, S.E., 2009. How I Learned to Design and Conduct Semi-structured Interviews: An Ongoing and Continuous Journey. The Qualitative Report, 14(3), pp.203-206.

Radix AP Jati, I., 2014. Local wisdom behind Tumpeng as an icon of Indonesian traditional cuisine. Nutrition \& Food Science, 44(4), pp.324-334.

Saptomo, A., 2010. Hukum dan kearifan lokal: revitalisasi hukum adat Nusantara, Grasindo.
Sawaki, A., Puhili, S., Kabey, E. \& Griapon, Y. G., 2015. Kearifan Lokal Sistem Mata Pencaharian Hidup Orang Mrem Di Distrik Kemtuk Gresi Kabupaten Jayapura. Kementerian Pendidikan Kebudayaan, Direktorat Jenderal Kebudayaan.

Schlosberg, D. and Carruthers, D., 2010. Indigenous struggles, environmental justice, and community capabilities. Global Environmental Politics, $10(4)$, pp.12-35.

Sumarmi, S., 2015. Local Wisdom of Osing People in Conserving Water Resources. Komunitas: International Journal of Indonesian Society and Culture, 7(1), pp.43-51.

Tipa, G. and Welch, R., 20o6. Comanagement of natural resources: issues of definition from an indigenous community perspective. The Journal of Applied Behavioral Science, 42(3), pp.373391.

Torrance, H., 2012. Triangulation, respondent validation, and democratic participation in mixed methods research. Journal of Mixed Methods Research, 1558689812437185.

Veland, S., Howitt, R., Dominey-Howes, D., Thomalla, F. and Houston, D., 2013. Procedural vulnerability: understanding environmental change in a remote indigenous community. Global Environmental Change, 23(1), pp.314-326.

\section{LEGISLATION}

Indonesia Government Regulation in Lieu of Law No.1 in 2008 (previously Law No.21 in 2001), article No. 43 chapter XI. The protection of the "adat" rights or local customary rights.

The decree of Regent at the Regency of Jayapura, No. 319 in 2014 on the Recognition and Protection of Indigenous People.

The decree of Regent at the Regency of Jayapura, No.320 in 2014 on the Formation of Indigenous Villages at the Regency of Jayapura. 